\title{
DEEP-WATER CORALS IN ATLANTIC CANADA: A REVIEW OF DFO RESEARCH (2001-2003)
}

\author{
DONALD C. GORDON JR. * AND ELLEN L.R. KENCHINGTON \\ Ecosystem Research Division, Science Branch \\ Department of Fisheries and Oceans, Maritimes Region \\ Bedford Institute of Oceanography \\ P.O. Box 1006 \\ Dartmouth, Nova Scotia B2Y $4 A 2$
}

Deep-water corals occur in Atlantic Canada at water depths in the general range of 200-1500 m. Prior to 2000, most knowledge of deep-water corals was anecdotal and based primarily on fishing bycatch information. During 2001-2003, in collaboration with university colleagues, the Department of Fisheries and Oceans (DFO) at the Bedford Institute of Oceanography investigated the distribution, abundance, habitat and biology of deep-water corals and their associated fauna under funding provided in part by the Environmental Studies Research Fund. Data were gathered from DFO groundfish surveys, the Fisheries Observer Program, interviews with fishers and dedicated research cruises with specialized imaging and sampling equipment. Nineteen coral taxa were collected or observed alive in their natural habitat; 6 Alcyonacea (soft corals), 7 Gorgonacea (horny corals), 5 Scleractinia (stony corals), and 1 Antipatharia (black corals). The results confirmed earlier observations that the Northeast Channel, the Gully and the Stone Fence are prime coral habitats. The first documented Lophelia reef complex in Atlantic Canada was found near the Stone Fence in the mouth of the Laurentian Channel. The distribution of deep-water corals is patchy and influenced by several environmental factors including substrate, temperature, salinity and currents. The average height of Primnoa and Paragorgia colonies was 30 and $57 \mathrm{~cm}$. At their estimated growth rates of 1.7 and $1 \mathrm{~cm} /$ year, respectively, the largest Primnoa colony observed was about 61 years old while the largest Paragorgia colony was about 180 years old. Deep-water corals host a rich associated fauna, and 114 taxa have been identified to date on Paragorgia and Primnoa in Atlantic Canada. Numerous species of fish have also been observed associated with deep-water corals, the most abundant being redfish. Damage from fishing gear was found to be most extensive at the Lophelia reef complex at the Stone Fence. A lower level of fishing damage was observed in the Northeast Channel while few indications of damage were observed in the Gully. The results of this program have been used by DFO to create coral conservation areas at the Northeast Channel $\left(424 \mathrm{~km}^{2}\right)$ and Stone Fence $\left(15 \mathrm{~km}^{2}\right)$ that are closed to bottom-fishing activities. Substantial knowledge gaps still exist, in particular quantitative information of deep-water corals at depths below $500 \mathrm{~m}$, and these are being addressed by continuing collaborative research by DFO and universities.

Les coraux abyssaux sont communs au Canada atlantique à des profondeurs allant de 200 à 1500 m. Avant 2000, la plupart des données sur les coraux abyssaux étaient de nature anecdotique et fondées principalement sur des données sur les prises accessoires lors d'activités de pêche. De 2001 à 2003, des chercheurs de l'Institut océanographique de Bedford du ministère des Pêches et des Océans (MPO), en collaboration avec des collègues du milieu universitaire, ont étudié la répartition, l'abondance, l'habitat et la biologie des coraux abyssaux et des espèces qui leurs sont associées dans le cadre d'un projet financé en partie par le Fonds pour l'étude de l'environnement. Les chercheurs ont recueilli des données obtenues dans le cadre de relevés du poisson

\footnotetext{
* Author to whom correspondence should be addressed
}

E-mail: gordond@mar.dfo-mpo.gc.ca 
de fond menés par le MPO, du Programme des observateurs des pêches, d'entrevues avec des pêcheurs et de croisières de recherche à bord de bateaux munis d'un équipement spécialisé d'échantillonnage et d'imagerie. Au total, 19 taxons de coraux ont été recueillis ou observés vivants dans leur habitat naturel : 6 Alcyonacea (coraux moux), 7 Gorgonacea (coraux cornés), 5 Scleractinia (coraux durs) et 1 Antipatharia (coreaux noirs). Les résultats confirment les observations antérieures selon lesquelles le chenal Nord-Est, le Goulet et le secteur de Stone Fence constituent des habitats de grande qualité pour les coraux. Le premier récif de Lophelia pertusa découvert au Canada atlantique est situé à proximité du secteur de Stone Fence, à l'embouchure du chenal Laurentien. La distribution des coraux abyssaux est éparse et dépend de plusieurs facteurs environnementaux, y compris le substrat, la température, la salinité et les courants. La hauteur moyenne des colonies de Primnoa et de Paragorgia observées était respectivement de 30 et de $57 \mathrm{~cm}$. D'après les taux de croissance estimés à 1,7 (Primnoa) et $1 \mathrm{~cm} /$ année (Paragorgia), la plus grande colonie de Primnoa observée était âgée d'environ 61 ans, tandis que la plus grande colonie de Paragorgia avait environ 180 ans. Les coraux abyssaux sont les hôtes d'une riche faune associée. Jusqu'à maintenant 114 taxons différents ont été identifiés sur les colonies de Paragorgia et de Primnoa au Canada atlantique. De nombreuses espèces de poissons ont également été observées en association avec les coraux abyssaux, la plus abondante étant le sébaste. Les plus importants dommages causés par des engins de pêche ont été observés au récif de Lophelia dans le secteur de Stone Fence. Des dommages moins importants attribuables à la pêche ont été observés dans le chenal Nord-Est, et peu d'indices de dommages ont été signalés dans le Goulet. Le MPO a utilisé les résultats du présent projet pour créer des zones de conservation des coraux dans le chenal Nord-Est (424 $\mathrm{km}^{2}$ ) et dans le secteur de Stone Fence $\left(15 \mathrm{~km}^{2}\right)$ où les activités de pêche de fond sont maintenant interdites. II existe encore des lacunes considérables dans les données, en particulier dans le cas des données quantitatives sur les coraux abyssaux à plus de $500 \mathrm{~m}$ de profondeur, et ces lacunes continuent d'être comblées par le biais des recherches conjointes menées par le MPO et des universités.

\section{INTRODUCTION}

Deep-water corals are found around the world and are important components of deep-water ecosystems. While their existence has been known for many years, they have received very little scientific attention compared to their shallow-water relatives, in large part because of the logistic difficulties in studying them. However, with the recent development of technologies such as ROVs and video platforms, it is now possible to study deep-water corals in their natural habitat. As a result, knowledge of deep-water corals is currently growing rapidly.

More than 700 species of deep-water corals occur world-wide (Freiwald et al. 2004). As described by Breeze et al. (1997), the term "coral" has been used to describe several different orders within the Phylum Cnidaria and the Subphylum Anthozoa. There are two classes of Anthozoans. The Hexacorallia include the true or stony corals (scleractinians), the antipatharian corals and sea anemones (actinarians) while the Octocorallia include the soft or leather corals (alcyonaceans), the horny corals (gorgonians) and the sea pens (pennatulaceans).

Most corals grow attached to stable substrate (e.g. cobbles, boulders, bedrock) while some are anchored in finer sediments and others are freeliving. All corals are epibenthic and most have arborescent growth forms. 
They can range in size from just a few centimetres to over $3 \mathrm{~m}$. Numerous deep-water corals provide habitat structure. Certain species of stony corals can form reef complexes that can be many meters high and extend horizontally for over a kilometer. Some species of large horny corals can form dense thickets commonly known as 'forests'. Deep-water corals are adapted to live without light and at relatively low temperatures $\left(4-13^{\circ} \mathrm{C}\right)$. They feed by capturing zooplankton and organic particles from the surrounding water. Growth rates are very low and colonies can be hundreds of years old. Biodiversity is higher in and around deep-water corals compared with adjacent areas. They provide shelter and feeding places for a wide variety of invertebrates and fish. It has also been suggested that they serve as spawning and nursery sites for some species. Additionally, the impressive ages documented for some colonies and the calcified accretions of their skeletons make them valuable for paleoclimatic studies. Deep-water corals are highly vulnerable to human activities, in particular fishing, and there is a strong international conservation movement for the protection of deep-water corals with calls for closed areas and bans on certain gear types.

Deep-water corals are common in Atlantic Canada. Early scientific reports include Verrill (1922) and Deichmann (1936). Using all available information which included the scientific literature, museum collections and bycatch reports, Breeze et al. (1997) reviewed the distribution and status of corals off Nova Scotia and reported the presence of 35 taxa, including 7 soft corals, 10 horny corals, 10 stony corals and 8 seapens. With the exception of soft corals, which are also found in shallow water, most deep-water corals in Atlantic Canada occur at depths between 200-1500 m along the edge of the continental shelf, in submarine canyons and in channels between fishing banks. Prime locations include the Northeast Channel, the Gully and the Stone Fence. Photographs of the more common deep-water coral taxa found off Nova Scotian are provided in Fig 1.

Human activities such as fishing and hydrocarbon extraction have the potential to seriously impact deep-water corals. Since our knowledge on deep-water corals and their habitats in Atlantic Canada remains sketchy, it has been necessary to collect more detailed information on their distribution, abundance and biology that can be used to make better informed management decisions regarding their protection from human activities. To this end, in 1997 the Department of Fisheries and Oceans (DFO) began to collect video and photographic information of deep-water corals on an opportunity basis at prime sites off Nova Scotia. A start was also made to capture information on deep-water corals collected as bycatch in the annual DFO groundfish trawl surveys. The results of this preliminary work were summarized in Maclsaac et al. (2001). Corals were observed at all sites surveyed and the results were in general agreement with the observations summarized by Breeze et al. (1997).

In 2001, a more formal DFO research program was established under funding from the Environmental Studies Research Funds (ESRF) and DFO. The ESRF is an oil and gas industry-funded program, administered by the 
Fig 1. Photographs taken by Campod of common corals off Nova Scotia in their natural habitat.

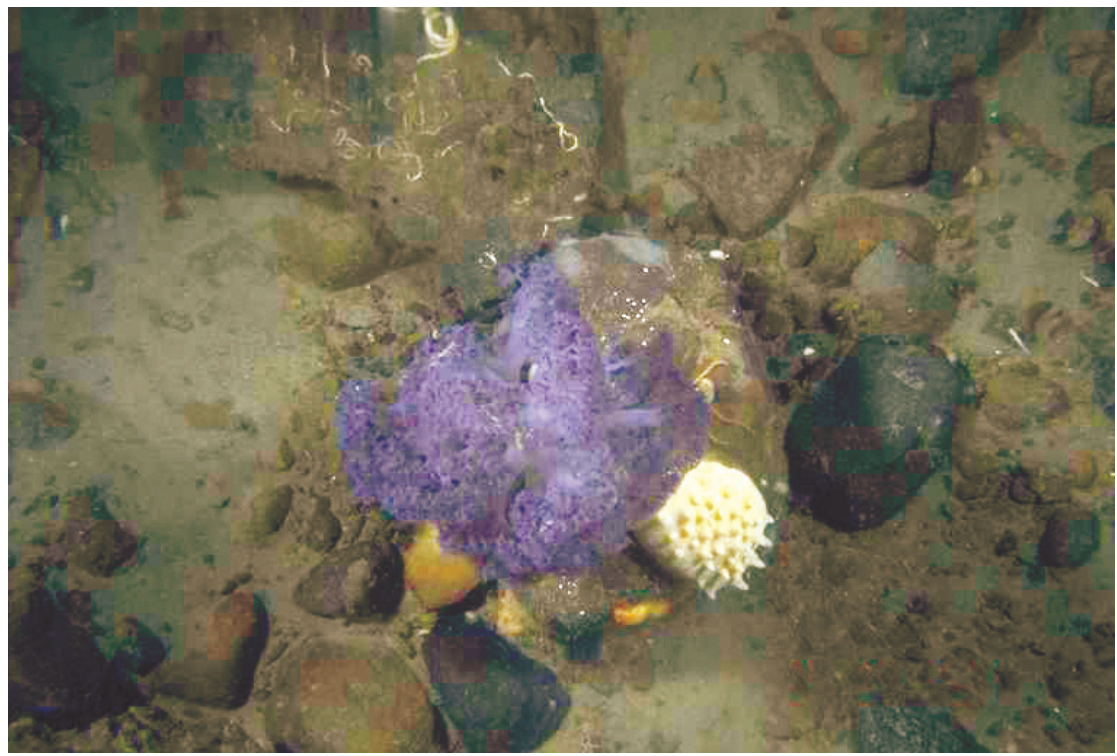

Fig 1A. A blue, broccoli-shaped soft coral attached to a cobble. The white object is an encrusting sponge.

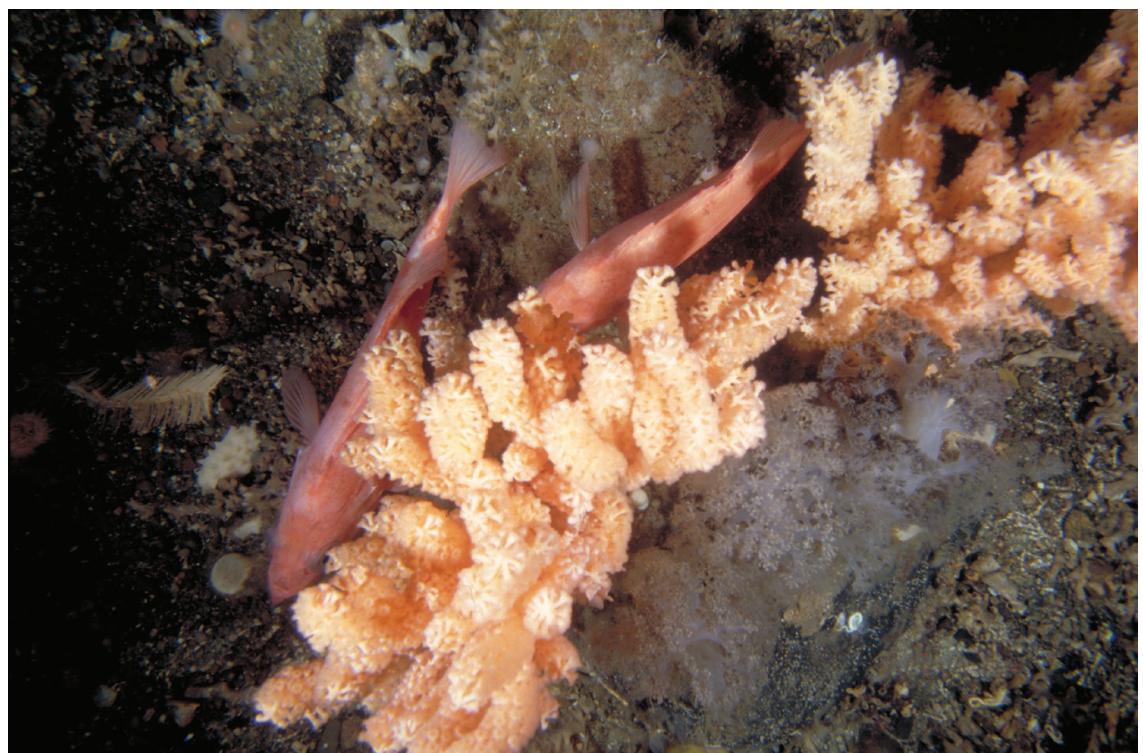

Fig 1B. The gorgonian Primnoa resedaeformis, commonly called sea corn, with soft corals and redfish seeking shelter. 


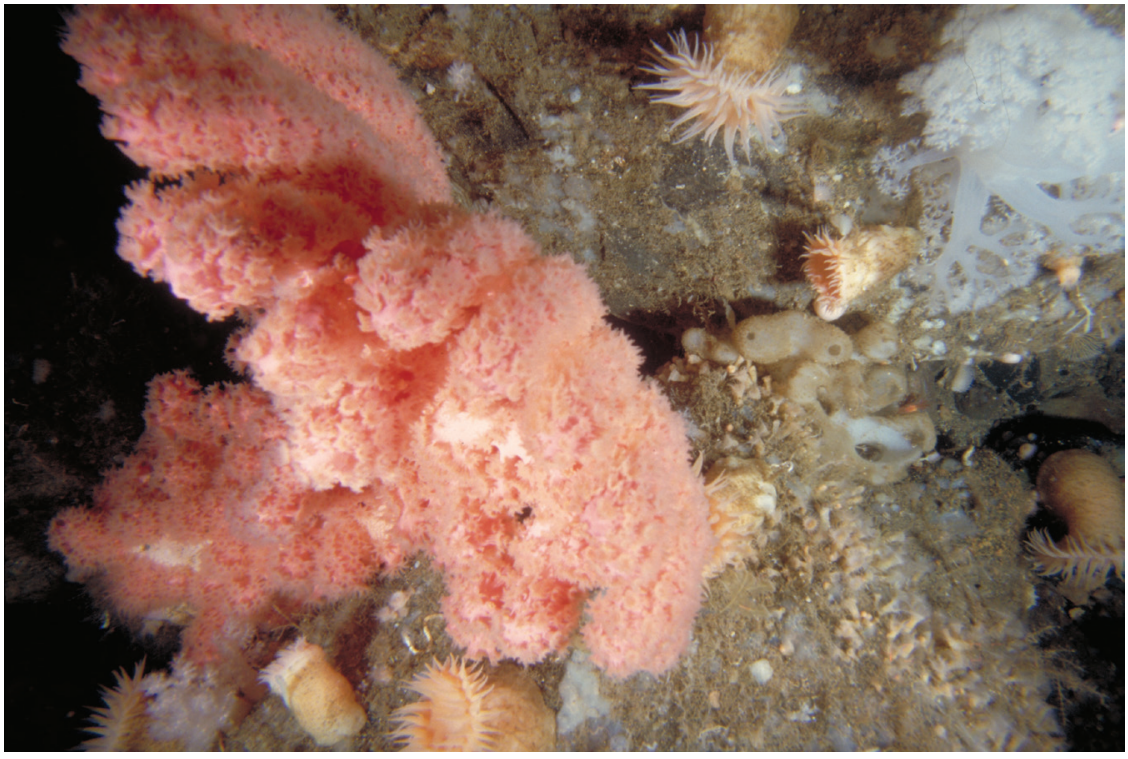

Fig 1C. The gorgonian Paragorgia arborea, commonly called bubblegum coral, with soft corals, anemones and sponges.

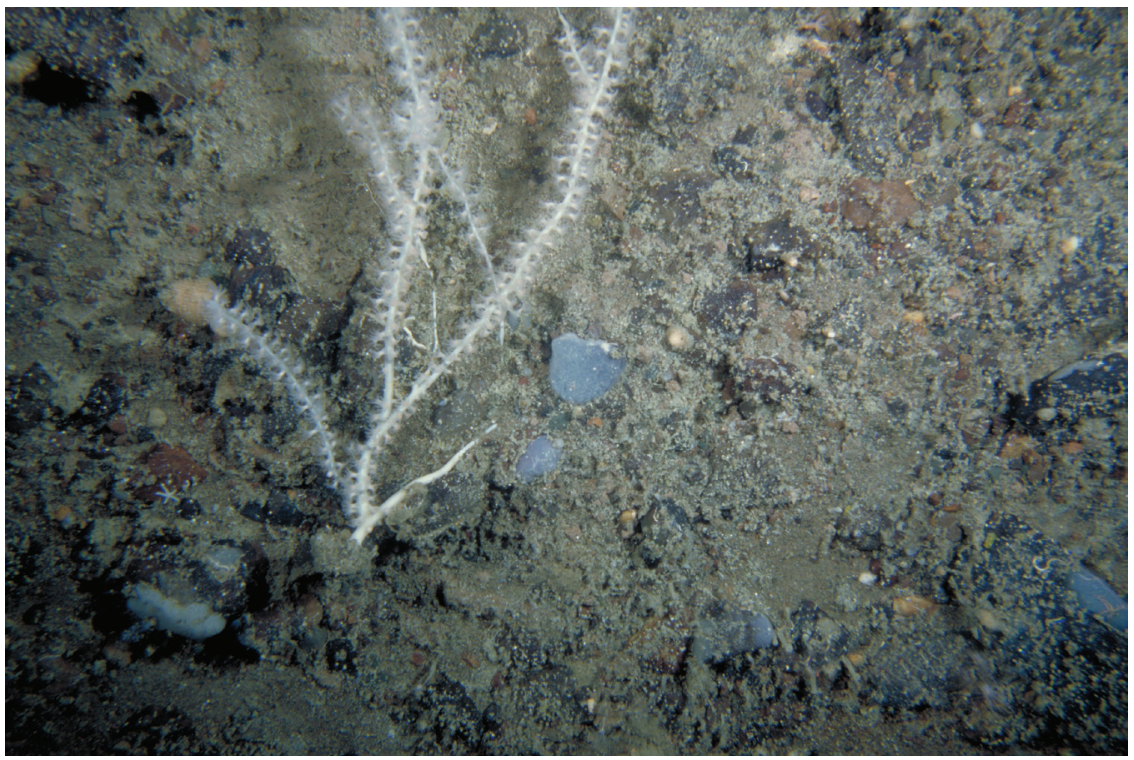

Fig 1D. The gorgonian Keratoisis ornate, also known as bamboo coral. 


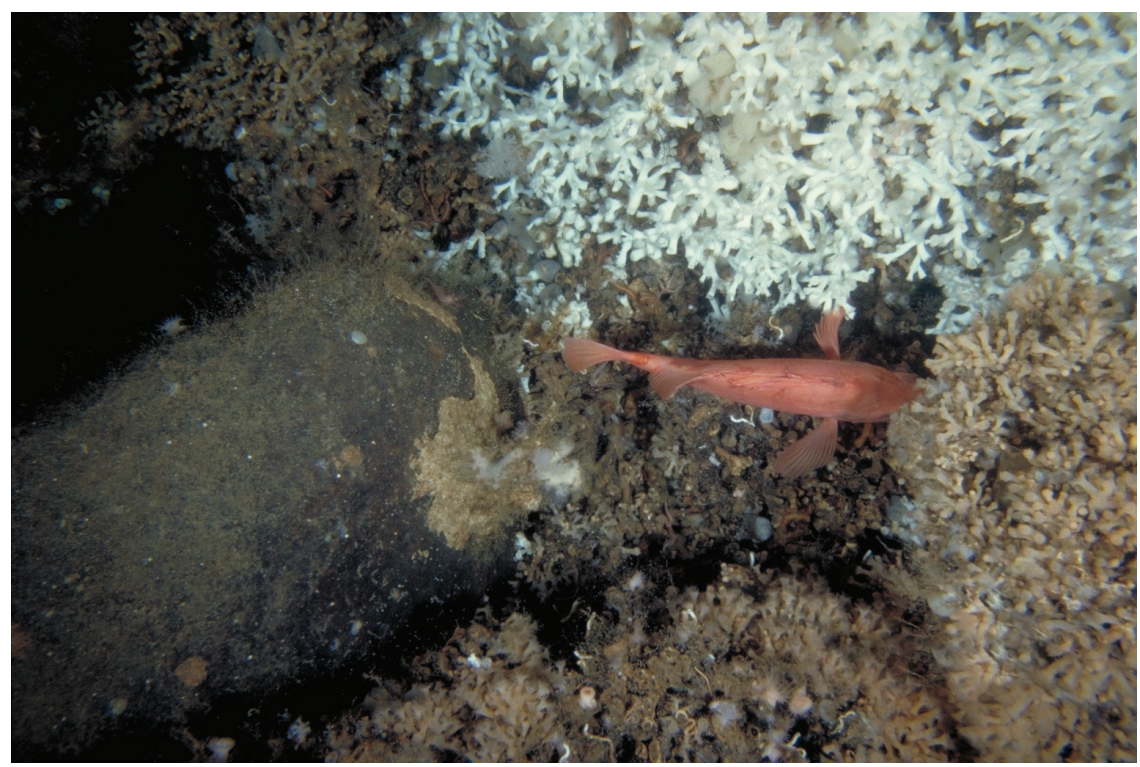

Fig 1E. The reef-building stony coral Lophelia pertusa with a redfish seeking shelter.

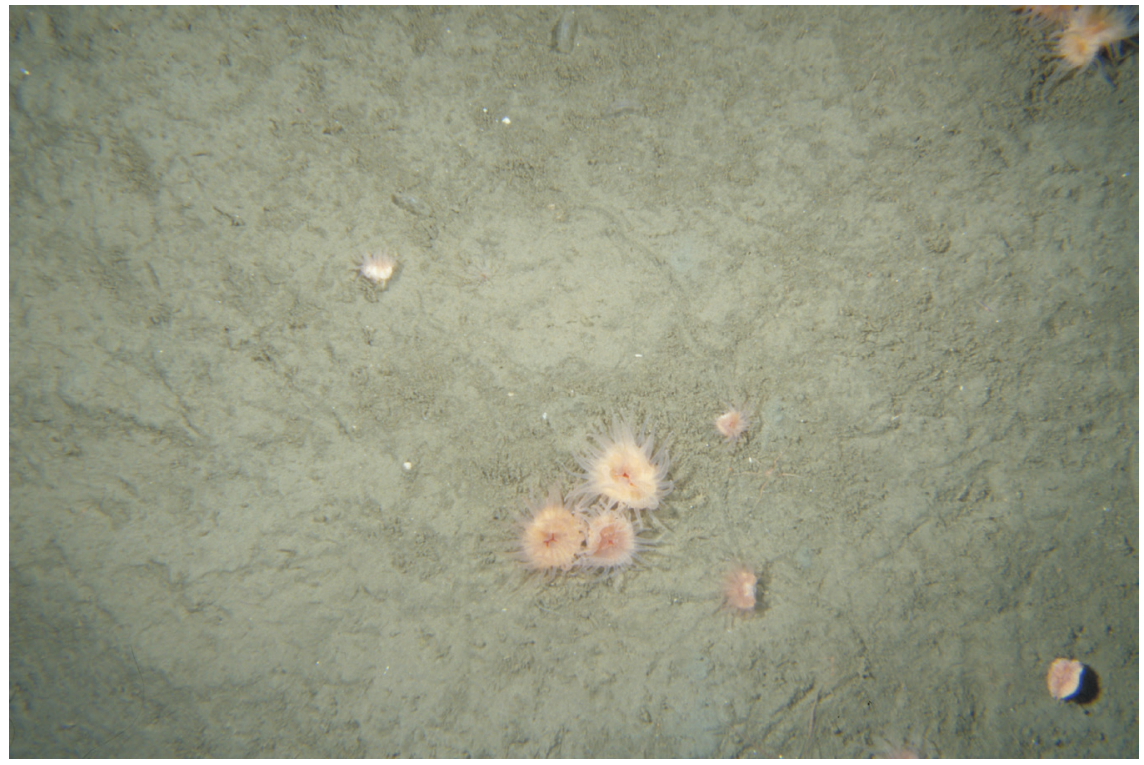

Fig 1D. The free-living stony coral Flabellum alabastrum on sandy seabed. 
National Energy Board, that supports environmental and social studies pertaining to exploration, development and production activities on Canadian frontier lands. Dr. Pål Mortensen, who had just finished his PhD on deep-water corals in Norway, was recruited as a Visiting Fellow through the National Scientific and Engineering Research Council (NSERC). In addition, Dr. Lene Buhl-Mortensen, a Norwegian specialist on deep-water benthic invertebrates, was hired through the Marine Invertebrate Diversity Initiative (MIDI). Funding was also provided to Ms. Susan Gass while she pursued her master's degree in environmental studies at Dalhousie University. This program was conducted with the assistance and collaboration of numerous government, university and industry colleagues.

During 2001-2003, a large amount of new data on deep-water corals in Atlantic Canada was collected and analyzed. Data sources included DFO groundfish trawl surveys, the Fisheries Observer Program, interviews with fishers and dedicated cruises to regions of particular interest using DFO research vessels and sampling equipment including Campod, Videograb and ROPOS. Some laboratory work with live corals was also done. This paper reviews the major results of this three-year research program. Full details can be found in the final report prepared for ESRF (Mortensen et al. 2006) and the numerous scientific papers referenced herein.

\section{DISTRIBUTION AND ABUNDANCE}

Corals were collected on four DFO groundfish trawl surveys on the Scotian Shelf, five off Newfoundland \& Labrador, and two in the Davis Strait. These surveys are shelf-wide and only a limited number of the sets returned corals. In total, 57 specimens were collected representing seven taxa (Gass 2002, Gass \& Willison 2005). As part of the Fisheries Observer Program, also shelf-wide, observers recorded 170 instances of corals being collected in commercial fishing gear. Six taxa were collected by four gear types (otter trawls, shrimp trawls, bottom longlines, and bottom gillnets) with longlines accounting for the greatest number of captures (Gass 2002, Gass \& Willison 2005). These records indicated the presence of corals ranging all the way from Jordan Basin in the Gulf of Maine northward to Davis Strait, generally along the edge of the continental shelf. Combining the two data sets, eight coral taxa were observed and their depth ranges are summarized in Table 1. The most frequently encountered taxa were the gorgonians Primnoa resedaeformis and Paragorgia arborea. The depth range of half the taxa extended well below $500 \mathrm{~m}$.

Of the 36 fishers interviewed in eastern Nova Scotia and Newfoundland \& Labrador, 26 had encountered deep-water corals while fishing with otter trawls, gillnets or longlines (Gass 2002, Gass \& Willison 2005). Eight taxa were identified (Table 2). With two exceptions, these were the same taxa observed in the DFO groundfish surveys and the Fisheries Observer Program (Table 1). Acanthogorgia armata was not recorded by the fishers, but one 
fisher produced a sample of coral which turned out to be the first identified antipatharian black coral in Atlantic Canada (Bathypathes sp.).

Table 1 Coral taxa and their depth ranges based on data from DFO groundfish trawl surveys and the Fisheries Observer Program. Sampling sites ranged from Jordan Basin in the Gulf of Maine northward to Davis Strait. From Gass (2002) and Gass \& Willison (2005).

\begin{tabular}{lcccc}
\hline Taxon & $\begin{array}{c}\text { No. of } \\
\text { Records }\end{array}$ & $\begin{array}{c}\text { Average } \\
\text { Depth }(\mathbf{m})\end{array}$ & $\begin{array}{c}\text { Minimum } \\
\text { Depth }(\mathbf{m})\end{array}$ & $\begin{array}{c}\text { Maximum } \\
\text { Depth }(\mathbf{m})\end{array}$ \\
\hline Primnoa resedaeformis & 134 & 319 & 166 & 467 \\
Paragorgia arborea & 41 & 361 & 249 & 720 \\
Acanella arbuscula & 11 & 622 & 281 & 1400 \\
Paramuricea spp. & 8 & 598 & 154 & 1159 \\
Acanthogorgia armata & 7 & 551 & 164 & 1400 \\
Flabellum spp. & 7 & 428 & 278 & 516 \\
Keratoisis ornata & 2 & 416 & 393 & 439 \\
Lophelia pertusa & 1 & 166 & - & - \\
\hline
\end{tabular}

Table 2 Coral taxa identified by fishers from eastern Nova Scotia and Newfoundland \& Labrador. From Gass (2002) and Gass \& Willison (2005).

\begin{tabular}{lc}
\hline Taxon & No. of Fishers \\
\hline Paragorgia arborea & 15 \\
Primnoa resedaeformis & 10 \\
Paramuricea spp. & 6 \\
Lophelia pertusa & 5 \\
Acanella arbuscula & 4 \\
Keratoisis ornata & 3 \\
Flabellum spp. & 2 \\
Bathypathes spp. & 1 \\
\hline
\end{tabular}

Video imagery was collected using Campod (a tethered video and still camera system) or ROPOS (a remotely operated vehicle) along 194 transects distributed along the shelf break between Georges Bank and the southern Grand Banks (Fig 2). Transects averaged about $600 \mathrm{~m}$ in length and were conducted in the general depth range of $200-500 \mathrm{~m}$. Restrictions on cable length prevented surveying in deeper waters. Transect locations were selected using various sources of information including published accounts, multibeam bathymetric maps, sidescan sonograms and anecdotal sources.

\section{Northeast Channel}

Video records were collected along 52 transects in the Northeast Channel using either Campod (45 transects) or ROPOS (7 transects) (Fig 2). As described in detail by Mortensen \& Buhl-Mortensen (2004), Mortensen et al. (2005) and Mortensen et al. (2006b), three Gorgonacea taxa were 


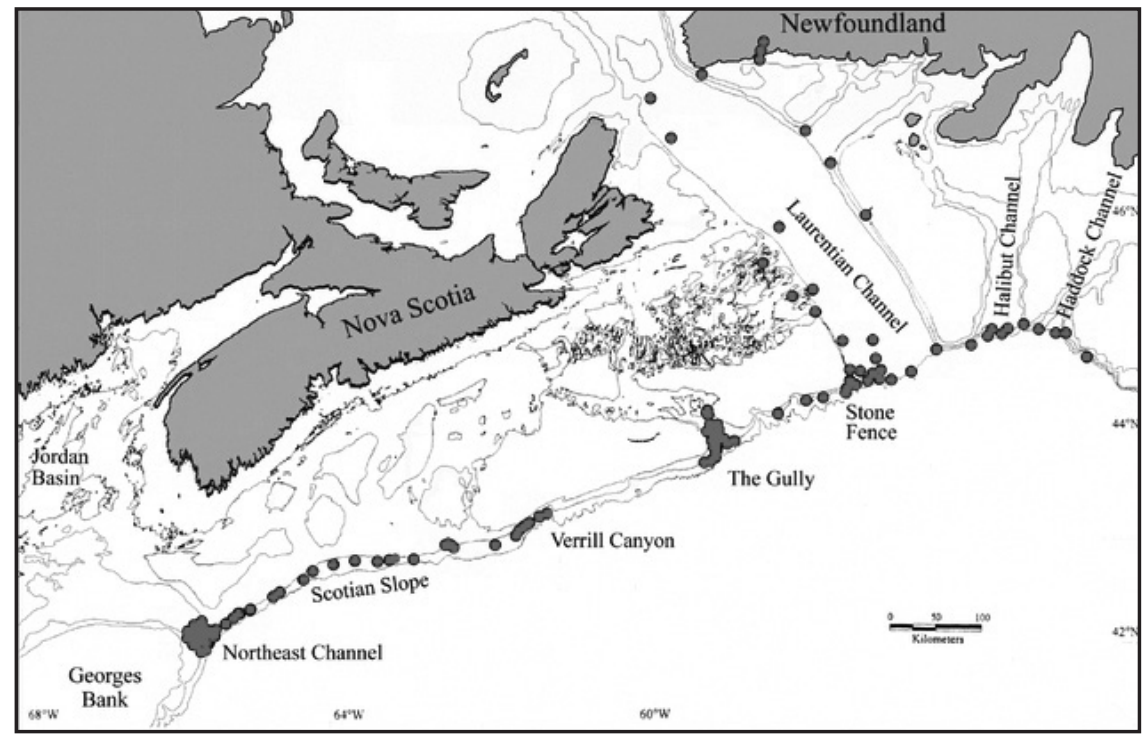

Fig 2. The location of sites in Atlantic Canada where video transects targeting deep-water corals were carried out using Campod (185 sites) or ROPOS (10 sites). Dawson Canyon is just to the east of Verrill Canyon. Not all sites had corals.

observed: Primnoa resedaeformis, Paragorgia arborea and Acanthogorgia armata (Table 3). P. resedaeformis was observed along $67 \%$ of the transects, $P$. arborea along $40 \%$ of the transects and $A$. armata along just $8 \%$ of the transects. P. resedaeformis was the most abundant taxon with an average abundance of 4.8 colonies per $100 \mathrm{~m}^{2}$. The shallowest observations of $P$. resedaeformis and $P$. arborea occurred at $196 \mathrm{~m}$ and $235 \mathrm{~m}$ while their highest densities were observed between 410 and $490 \mathrm{~m}$. A. armata was observed between 231 and $364 \mathrm{~m}$.

Table 3 Summary of video observations of deep-water corals in the Northeast Channel. Taxon, number of specimens observed, the number of transects a taxon was observed on average abundance (colonies per $100 \mathrm{~m}^{2}$ ), on transects where observed and depth range $(\mathrm{m})$. Total number of transects was 52 and total length of all transects was $34 \mathrm{~km}$. From Mortensen et al. (2005), Mortensen \& Buhl-Mortensen (2004) and Mortensen et al. (2006b).

\begin{tabular}{llcccc}
\hline Order & Taxon & Specimens & Transects & $\begin{array}{c}\text { Average } \\
\text { Abundance }\end{array}$ & $\begin{array}{c}\text { Depth } \\
\text { Range }\end{array}$ \\
\hline Gorgonacea & Acanthogorgia armata & 212 & 4 & 0.5 & $231-364$ \\
& Paragorgia arborea & 322 & 21 & 0.6 & $235-498$ \\
& Primnoa resedaeformis & 2663 & 35 & 4.8 & $196-498$ \\
\hline
\end{tabular}




\section{Scotian Slope}

Video transects were made using Campod at 24 locations along the Scotian Slope between the Northeast Channel and Verrill Canyon (Fig 2). As described in detail by Mortensen et al. (2006b), six taxa were observed: 2 Alcyonacea and 4 Scleractinia (Table 4). The cup coral Flabellum spp. was the most common taxon occurring along $54 \%$ of the transects and averaging 29.2 individuals per $100 \mathrm{~m}^{2}$. Some seapens were also observed, but no gorgonians. Four ROPOS video transects in Verrill and Dawson Canyons also indicated the presence of soft corals and cup corals but no gorgonians.

Table 4 Summary of video observations of deep-water corals along the Nova Scotian Slope. Taxon, number of specimens observed, the number of transects a taxon was observed on, average abundance (colonies or individuals per $100 \mathrm{~m}^{2}$ ) on transects where observed, and depth range $(\mathrm{m})$. Total number of transects was 24 and total length of all transects was $16 \mathrm{~km}$. From Mortensen et al. (2006b).

\begin{tabular}{llcccc}
\hline Order & Taxon & Specimens & Transects & $\begin{array}{c}\text { Average } \\
\text { Abundance }\end{array}$ & $\begin{array}{c}\text { Depth } \\
\text { Range }\end{array}$ \\
\hline Alcyonacea & Duva florida & 3 & 2 & 0.01 & $367-427$ \\
& Nephtheidae (white) & 1 & 1 & $<0.01$ & 427 \\
Scleractinia & Flabellum alabastrum & 292 & 11 & 1.2 & $346-500$ \\
& Flabellum macandrewi & 49 & 4 & 0.2 & $420-500$ \\
& Flabellum cf. angulare & 303 & 7 & 1.3 & $346-492$ \\
& Flabellum spp. & 7040 & 13 & 29.2 & $346-492$ \\
\hline
\end{tabular}

\section{The Gully}

Campod video transects were run at 49 sites in the Gully (Fig 2). Full details are given in Mortensen \& Buhl-Mortensen (2005a) and Mortensen et al. (2006b). Except for shallow water near the head, corals were common throughout the Gully. A total of 16 taxa were identified: 5 Alcyonacea, 6 Gorgonacea and 5 Scleractinia (Table 5). Up to 11 taxa were found on a single transect. The shallowest observed depth for alcyonarians was $172 \mathrm{~m}$ and about $340 \mathrm{~m}$ for gorgonians and scleractinians. Again, nothing can be said about the maximum depths of corals because of the restrictions set by the cable length of Campod. However, photographs taken in the outer Gully using a Benthos deep-sea camera indicate that Keratoisis ornata extends to at least $767 \mathrm{~m}$, Radicipes spp. to at least $1287 \mathrm{~m}$, and Anthomastus grandiflorus to at least $1326 \mathrm{~m}$ (Kostylev 2000). The most abundant taxon was Flabellum cf. angulare which had an average abundance of 94.1 individuals per $100 \mathrm{~m}^{2}$ (Table 5). The most abundant colonial coral was the soft coral Duva florida which had an average abundance of 5.2 colonies per $100 \mathrm{~m}^{2}$ while the most abundant gorgonian was Acanella arbuscula which had an average abundance of 3.4 colonies per $100 \mathrm{~m}^{2}$. The Gully had the highest diversity of corals of all the regions studied but the abundance of colonial corals was lower than observed in the Northeast Channel. 
Table 5 Summary of video observations of deep-water corals in the Gully. Taxon, number of specimens observed, the number of transects a taxon was observed on, average abundance (colonies or individuals per $100 \mathrm{~m}^{2}$ ) on transects where observed, and depth range $(\mathrm{m})$. Total number of transects was 49 and total length of all transects was $17 \mathrm{~km}$. From Mortensen \& Buhl-Mortensen (2005a) and Mortensen et al. (2006b).

\begin{tabular}{llrccc}
\hline Order & Taxon & Specimens & Transects & $\begin{array}{c}\text { Average } \\
\text { Abundance }\end{array}$ & $\begin{array}{c}\text { Depth } \\
\text { Range }\end{array}$ \\
\hline \multirow{2}{*}{ Alcyonacea } & Anthomastus grandiflorus & 17 & 6 & 0.2 & $399-523$ \\
& Duva florida & 1498 & 18 & 5.2 & $172-537$ \\
& Nephtheidae (blue) & 160 & 9 & 2.3 & $270-446$ \\
& Nephtheidae (white) & 186 & 14 & 1.8 & $287-539$ \\
& Nephtheidae spp. & 403 & 13 & 2.1 & $237-538$ \\
Gorgonacea & Acanella arbuscula & 74 & 5 & 3.4 & $404-540$ \\
& Acanthogorgia armata & 32 & 4 & 0.7 & $346-493$ \\
& Keratoisis ornata & 63 & 8 & 0.9 & $396-509$ \\
& Paragorgia arborea & 28 & 7 & 0.3 & $341-495$ \\
& Primnoa resedaeformis & 108 & 4 & 2.0 & $388-516$ \\
& Radicipes gracilis & 40 & 7 & 0.7 & $404-535$ \\
Scleractinia & Flabellum alabastrum & 116 & 10 & 0.9 & $341-541$ \\
& Flabellum macandrewi & 3 & 1 & - & 439 \\
& Flabellum spp. & 3396 & 12 & 12.1 & $404-439$ \\
& Flabellum cf. angulare & 1124 & 3 & 94.1 & $337-541$ \\
& Lophelia pertusa & 1 & 1 & - & 450 \\
\hline
\end{tabular}

\section{Stone Fence}

Campod video transects were made at 39 sites at the Stone Fence in the mouth of the Laurentian Channel (Fig 2). Full details are provided in Mortensen et al. (2006b). Corals were encountered along all transects. Eight taxa were observed: 2 Alcyonacea, 4 Gorgonacea and 2 Scleractinia (Table 6). The most abundant taxon was Duva florida which had an

Table 6 Summary of video observations of deep-water corals at the Stone Fence in the mouth of the Laurentian Channel. Taxon, number of specimens observed, the number of transects a taxon was observed on, average abundance (colonies or individuals per $100 \mathrm{~m} 2$ ) on transects where observed, and depth range $(\mathrm{m})$. Total number of transects was 39 and total length of all transects was $40 \mathrm{~km}$. From Mortensen et al. (2006b).

\begin{tabular}{llcccc}
\hline Order & Taxon & Specimens & Transects & $\begin{array}{c}\text { Average } \\
\text { Abundance }\end{array}$ & $\begin{array}{c}\text { Depth } \\
\text { Range }\end{array}$ \\
\hline Alcyonacea & Anthomastus grandiflorus & 521 & 22 & 1.0 & $260-502$ \\
& Duva florida & 1449 & 20 & 2.8 & $260-500$ \\
Gorgonacea & Acanthogorgia armata & 288 & 24 & 1.6 & $260-502$ \\
& Keratoisis ornata & 44 & 17 & 0.1 & $271-502$ \\
& Primnoa resedaeformis & 297 & 17 & 0.9 & $260-414$ \\
& Paragorgia arborea & 115 & 20 & 0.4 & $260-502$ \\
Scleractinia & Lophelia pertusa (live) & 67 & 8 & 0.01 & $260-400$ \\
& Flabellum spp. & & & 0.2 & \\
\hline
\end{tabular}


average abundance of 2.8 colonies per $100 \mathrm{~m}^{2}$. Of particular note at this site was the discovery of a Lophelia pertusa reef complex approximately 490 by $1300 \mathrm{~m}$ (about $0.6 \mathrm{~km}^{2}$ ) comprised of live colonies, dead blocks and skeletal rubble. Most of the living colonies were observed between 300 and $320 \mathrm{~m}$. Dead L. pertusa, both rubble and blocks, was much more abundant than living coral. This marked the first time that $L$. pertusa has been seen alive in its natural habitat in Atlantic Canada. In general, both the abundance and diversity of corals at the Stone Fence were lower than found in the Gully.

\section{Laurentian Channel}

Campod video transects were run at 19 sites in the Laurentian Channel (Fig 2). Full details are given in Mortensen et al. (2006b). Corals were found along $45 \%$ of the transects. Seven taxa were identified: 2 Alcyonacea, 3 Gorgonacea and 2 Scleractinia (Table 7). Depth range was 245-414 m. In general, the abundance of corals was low with a maximum for Acanthogorgia armata of 1.1 colonies per $100 \mathrm{~m}^{2}$.

Table 7 Summary of video observations of deep-water corals in the Laurentian Channel (excluding the Stone Fence region). Taxon, number of specimens observed, the number of transects a taxon was observed on, average abundance (colonies or individuals per $100 \mathrm{~m} 2$ ) on transects where observed, and depth range $(\mathrm{m})$. Total number of transects was 19 and total length of all transects was $7.2 \mathrm{~km}$. From Mortensen et al. (2006b).

\begin{tabular}{llcccc}
\hline Order & Taxon & Specimens & Transects & $\begin{array}{c}\text { Average } \\
\text { Abundance }\end{array}$ & $\begin{array}{c}\text { Depth } \\
\text { Range }\end{array}$ \\
\hline Alcyonacea & Duva florida & 8 & 1 & 1.0 & 340 \\
& Gersemia rubiformis & 17 & 1 & 0.5 & 245 \\
Gorgonacea & Acanthogorgia armata & 60 & 1 & 1.1 & 340 \\
& Acanella arbuscula & & & 0.3 & \\
& Radicipes gracilis & 1 & 1 & 0.1 & 348 \\
Scleractinia & Flabellum alabastrum & 34 & 4 & 0.7 & $305-414$ \\
& Flabellum spp. & 54 & 7 & 0.6 & $305-414$ \\
\hline
\end{tabular}

\section{Southern Edge of the Grand Banks}

Campod video transects were run at 11 sites in the Haddock and Halibut Channels along the southern edge of the Grand Banks (Fig 2). Full details are given in Mortensen et al. (2006b). Corals were found along $64 \%$ of the transects. Eight taxa were identified: 3 Alcyonacea, 3 Gorgonacea and 2 Scleractinia (Table 8). In general, abundance was low with the most abundant taxon being Flabellum alabastrum which had an average abundance of 1.9 colonies per $100 \mathrm{~m}^{2}$. 
Table 8 Summary of video observations of deep-water corals in the Haddock and Halibut Channels along the southern edge of the Grand Banks. Taxon, number of specimens observed, the number of transects a taxon was observed on, average abundance (colonies or individuals per $10 \mathrm{~m} 2$ ) on transects where observed, and depth range (m)s. Total number of transects was 11 and total length of all transects was 4.2 km. From Mortensen et al. (2006b).

\begin{tabular}{llcccc}
\hline Order & Taxon & Specimens & Transects & $\begin{array}{c}\text { Average } \\
\text { Abundance }\end{array}$ & $\begin{array}{c}\text { Depth } \\
\text { Range }\end{array}$ \\
\hline Alcyonacea & Anthomastus grandiflorus & 2 & 1 & 0.1 & 421 \\
& Duva florida & 107 & 4 & 1.5 & 504 \\
& Nephtheidae (white) & 16 & 4 & 0.3 & 409 \\
Gorgonacea & Acanella arbuscula & 169 & 2 & 0.1 & $409-421$ \\
& Acanthogorgia armata & 38 & 6 & 0.4 & $370-518$ \\
& Radicipes gracilis & 15 & 1 & 0.9 & 409 \\
Scleractinia & Flabellum alabastrum & 177 & 4 & 1.9 & $409-518$ \\
& Flabellum spp. & 158 & 5 & 1.3 & $370-518$ \\
\hline
\end{tabular}

All taxa observed during this program are listed in Table 9. A total of 19 taxa were positively identified including 6 Alcyonacea, 7 Gorgonacea, 5 Scleractinia and 1 Antipatharia. All these taxa were observed in the video footage except Paramuricea spp. and Bathypathes spp. None of the Alcyonacea taxa were detected in the groundfish surveys and observer program or by fishers, data sources which are dependent on fishing gear. These taxa are relatively small in size and they were probably not caught, ignored or misidentified. While much more costly, video surveys are obviously the preferred option, especially since they are non-destructive and provide quantitative data. Additional taxa have been reported to occur in Atlantic Canada (Breeze et al. 1997 and Mortensen et al. 2006b) but were not observed during this program. Further field studies should confirm the occurrence of additional deep-water coral taxa and extend the ranges of those already confirmed.

\section{HABITAT CHARACTERISTICS}

\section{Northeast Channel}

As reported by Mortensen \& Buhl-Mortensen (2004) and Mortensen et al. (2005b), the distribution of the three gorgonian species observed (Primnoa resedaeformis, Paragorgia arborea, and Acanthogorgia armata) was patchy and restricted to areas with cobbles and boulders. No corals were observed attached to sand or pebbles. Boulders were commonly observed on most transects but seldom covered more than $50 \%$ of the seabed. For all transects, the percent cover of cobble and boulder averaged $21 \%$ and $9 \%$, respectively. Many boulders had no corals attached indicating that suitable substrate is not limiting. Large colonies of $P$. arborea were observed almost exclusively on boulders, whereas smaller colonies were often observed on cobbles as well. P. resedaeformis occurred on both cobbles and boulders, 
Table 9 Deep-water coral taxa identified during this program (2001-2003) according to data source.

\begin{tabular}{|c|c|c|c|c|}
\hline Order & Taxon & $\begin{array}{l}\text { Groundfish Surveys } \\
\text { and Observer Program }\end{array}$ & Fishers & Video \\
\hline \multirow[t]{6}{*}{ Alcyonacea } & Anthomastus grandiflorus & & & $\mathrm{X}$ \\
\hline & Duva florida & & & $\mathrm{x}$ \\
\hline & Gersemia rubiformis & & & $\mathrm{X}$ \\
\hline & Nephtheidae (blue) & & & $\mathrm{X}$ \\
\hline & Nephtheidae (white) & & & $x$ \\
\hline & Nephtheidae spp. & & & $x$ \\
\hline \multirow[t]{7}{*}{ Gorgonacea } & Acanella arbuscula & $\mathrm{X}$ & $\mathrm{X}$ & $x$ \\
\hline & Acanthogorgia armata & $X$ & & $x$ \\
\hline & Keratoisis ornata & $x$ & $\mathrm{X}$ & $x$ \\
\hline & Paragorgia arborea & $x$ & $x$ & $x$ \\
\hline & Primnoa resedaeformis & $x$ & $x$ & $x$ \\
\hline & Radicipes gracilis & & & $\mathrm{X}$ \\
\hline & Paramuricea spp. & $\mathrm{X}$ & $\mathrm{X}$ & \\
\hline \multirow[t]{5}{*}{ Scleractinia } & Flabellum alabastrum & & & $x$ \\
\hline & Flabellum macandrewi & & & $\mathrm{X}$ \\
\hline & Flabellum spp. & $\mathrm{X}$ & $\mathrm{X}$ & $x$ \\
\hline & Flabellum cf. angulare & & & $\mathrm{x}$ \\
\hline & Lophelia pertusa & $x$ & $\mathrm{X}$ & $\mathrm{X}$ \\
\hline Antipatharia & Bathypathes spp. & & $x$ & \\
\hline
\end{tabular}

while $A$. armata was found only on cobbles. Both $P$. resedaeformis and $P$. arborea were frequently found on the same boulder. There was no sign of competitive exclusion at any spatial scale.

Corals were more common in the outer part of the Channel compared to the inner (Mortensen \& Buhl-Mortensen 2004). Transects with the highest abundance of corals were characterized by depths greater than 400 $\mathrm{m}$, a maximum water temperature less than $9.2^{\circ} \mathrm{C}$, and a relatively high percent coverage of cobble and boulders. High temperatures probably control the upper depth limit of the corals. Primnoa resedaeformis seems to tolerate slightly higher temperatures than Paragorgia arborea (about 13 ${ }^{\circ} \mathrm{C}$ compared to about $10^{\circ} \mathrm{C}$ ). Abundance of both species was negatively correlated with average temperature and positively correlated with cobbles. Together, temperature, percent cobble and salinity accounted for $38 \%$ of the variance of $P$. resedaeformis compared to $15 \%$ for $P$. arborea. The overall distribution of corals appears to be related to the general circulation. Corals were almost totally absent on the northern side along the flanks of Browns Bank which has a net inflow whereas they were most abundant on the southern side which has a net outflow (Ramp et al. 1985).

\section{Scotian Slope}

The seabed at the slope transects examined was composed of soft sediments (Mortensen et al. 2006b). The only hard substrate was some very sparse cobble. No boulders were observed. Individuals of the dominant taxon (Flabellum spp.) were small and unattached. When observed, the soft coral Duva florida was attached to cobble. 


\section{The Gully}

As described by Mortensen \& Buhl-Mortensen (2005a), the Gully has a high diversity of habitats including steep bedrock outcrops, high relief ledges, gravel, sand and mud. The area of cobble and boulder (9\%) was much less than observed in the Northeast Channel (21\%). Sand was more common in the shallow inner part of the Gully while mud was more common in the deeper outer part. Sharp changes in substrate were often related to changes in slope. Bottom temperature in the Gully ranged between 1.9 and $10.3 \mathrm{C}$ and averaged $5.3 \mathrm{C}$. Salinity was generally between 34.55 and 34.86 .

Corals were found in most parts of the canyon (Mortensen \& BuhlMortensen 2005a and Mortensen et al. 2006b). Most were found deeper than $350 \mathrm{~m}$. Substrate in the shallow inner Gully consists mainly of muddy sand. The only corals observed were alcyonarians attached to scattered cobbles. In other parts of the Gully above the shelf break, the seabed was muddier and Flabellum spp. was abundant. Below the shelf break, the seabed becomes coarser and has patches of gravel that support a great diversity of suspension feeders. Here, the gorgonian Acanthogorgia armata and the alcyonarian Anthomastus grandiflorus were observed on cobbles and boulders. On transects in small side canyons, a rugged terrain was observed with extensive outcrops of semi-consolidated mudstone. Soft corals were situated on the crests of these structures, also Paragorgia arborea and Primnoa resedaeformis where mudstone was exposed. Elsewhere, $P$. arborea and $P$. resedaeformis were more commonly found on boulders. The gorgonian Keratoisis ornata was often observed on cobbles and boulders in the bottom of small channels. Flabellum spp. and Acanella arbuscula were generally associated with the finer, more level sediments in the outer part of the Gully. K. ornata, P. resedaeformis and Nephtheidae spp. were associated with steep slope and exposed mudstone. Except for $A$. arbuscula and Radicipes gracilis, which are anchored in soft sediment, gorgonians were mainly confined to areas with cobble and boulders, and in a few cases semi-consolidated mudstone. On the other hand, the soft corals utilized a wide range of substrates including the semi-consolidated mudstone.

Multivariate analyses by Mortensen \& Buhl-Mortensen (2005a) indicated that the distribution of corals in the Gully is controlled primarily by distance along the axis, salinity, substrate type and slope. However, much of the variation in coral distribution could not be accounted for by environmental variables. As in the Northeast Channel, the highest abundance of corals is found on the western side of the canyon and this is presumably related to residual circulation patterns.

\section{Stone Fence}

The video observations indicated the presence of a Lophelia pertusa reef complex of smaller coral mounds within an area of approximately 490 x 1300 m (Mortensen et al. 2006a). Locally, L. pertusa rubble, with some infill of finer sediment, covered up to $100 \%$ of the bottom. L. pertusa oc- 
curred as live or dead fragments in clusters in isolated rubble areas typically extending horizontally 10 to $100 \mathrm{~m}$. These rubble areas probably represent former reefs. The height of these accumulations of coral (both rubble and larger dead fragments) was difficult to measure but was estimated to be about $3 \mathrm{~m}$. Relatively small colonies of Paragoria arborea were observed and many of these were tilted or attached to the sides of boulders. The location of the reef complex on the western side of the mouth of the Laurentian Channel is thought to be due in part to higher food concentrations in outflowing water.

\section{Laurentian Channel}

In general, the relatively low abundance of corals in the Laurentian Channel probably reflects the low cover of cobble and boulder in this area (Mortensen et al. 2006b).

\section{MORPHOLOGY, GROWTH, AND BEHAVIOUR}

As described by Mortensen \& Buhl-Mortensen (2005b), the height of Paragorgia arborea colonies ranged from 5 to $180 \mathrm{~cm}$ with an average of $57 \mathrm{~cm}$, while the height of Primnoa resedaeformis colonies ranged from 5 to $86 \mathrm{~cm}$ with an average of $30 \mathrm{~cm}$. There was a significant correlation between height and base diameter for both species. P. arborea colonies generally had thicker trunks and branches than $P$. resedaeformis. Most $P$. arborea colonies were more or less circular in outline while $P$. resedaeformis colonies were more oblong with conical branches widening at the top. The height of $P$. arborea colonies was positively correlated to the size of the boulders to which they were attached. It appears that when maximum height exceeds approximately twice the diameter of the boulder, strong currents can roll them over resulting in a changed growth direction. A similar relation has been reported in Knight Inlet, British Columbia (Tunnicliffe \& Syvitsky 1983).

Paragorgia arborea was observed to occur in three colour varities: salmon, red and white (Mortensen \& Buhl-Mortensen 2005b). The red and white varieties each contributed $41 \%$ to the population while $18 \%$ of the colonies were salmon-coloured. On average, salmon-coloured $P$. arborea colonies were taller than the red and white varieties. As the varieties co-occur, these differences in colour are thought to be related to genetics and not environmental factors.

Most Paragorgia arborea colonies larger than $50 \mathrm{~cm}$ were concaveshaped and oriented into the prevailing near-bottom current (Mortensen \& Buhl-Mortensen 2005b). Polyp density was higher for Primnoa resedaeformis than $P$. arborea but for both species polyp density was greatest on the outer branches. $P$. arborea most commonly occurred on the top of boulders. P. resedaeformis did not reflect the main current direction to the same degree as $P$. arborea but commonly occurred on the up-current side of boulders. The different height, morphology and position on boulders of 
these two gorgonian species suggests they utilize different food sources. $P$. resedaeformis seems to be adapted to a near bottom environment with turbulent currents while $P$. arborea seems more adapted to uni- or bi-directional currents higher off the seabed and develops planar colonies perpendicular to the prevailing current. The orientation of large $P$. arborea colonies provides a picture of near bottom-current patterns integrated over long time spans. In the Northeast Channel, their parabolic colony form was observed to face into the outflowing current, presumably to maximize the capture of food particles.

Based on counting the rings in cross-sections of colony bases, the oldest Primnoa resedaeformis colony collected was 61 years (Mortensen \& Buhl-Mortensen 2005b). The relationship between height and age indicated an average growth rate of $1.7 \mathrm{~cm} / \mathrm{y}$ for $P$. resedaeformis. X-ray images of skeletal sections of Paragorgia arborea showed clear growth bands but since it was not certain what time scales these bands indicated they could not be used for ageing. However, other data sources reviewed by Mortensen \& Buhl-Mortensen (2005b) suggest an average growth rate of approximately $1 \mathrm{~cm} /$ year. This means that the largest $P$. arborea colony measured in this study (180 cm in height) was on the order of 180 years old.

Live specimens of Flabellum alabastrum, Duva florida, Anthomastus grandiflorus, Primnoa resedaeformis, Keratoisis ornata, Acanella arbuscula, Acanthogorgia armata, and Paragorgia arborea were successfully collected by ROPOS and Videograb and transported to the BIO Fish Lab. $D$. florida and $F$. alabastrum turned out to be the easiest taxa to maintain in aquaria and some specimens survived as long as 21 months feeding on unfiltered Bedford Basin water which contained abundant zooplankton and organic particles. This experience indicates that it is feasible to conduct experiments on deep-water corals if healthy specimens can be obtained, especially $D$. florida and $F$. alabastrum.

Laboratory observations were made on the behaviour of Duva florida, Flabellum alabastrum and Anthomastus grandiflorus, in particular patterns in body extension and contraction. The results indicate that there are differences in feeding behaviour and that the ability to handle food particles of different size seems to be related to the anatomy of the polyps. One observation of note is the ability of $F$. alabastrum to expand its body size more than ten times. This behaviour may be related to food uptake and physiology, or it may represent a way of escaping an area by increasing buoyancy and drag and moving with the bottom current. This behaviour was also observed in the field. F. alabastrum was also observed to move slowly, leaving tracks in the sediment, but the mechanism for doing this is not understood. The respiration rate of $F$. alabastrum was measured and found to be quite low. 


\section{ASSOCIATED FAUNA}

Deep-water corals provide structural habitat that can be used by other species. This includes the surface of living and dead corals, cavities inside dead skeletons and the spaces between coral branches. Branches can reach up into stronger currents above the benthic boundary layer and feeding advantages are shared with attached filter-feeding organisms. Associated species can also feed on detritus and micro-organisms trapped in coral mucous.

Aliterature review revealed that more than 980 species have been recorded on deep-water corals (Buhl-Mortensen \& Mortensen 2004a). Of these, 112 can be characterized as symbionts of which 30 species are obligate to corals. Fifty-three percent of these obligates are parasites and $47 \%$ are commensals. There are no clear examples of symbiotic relationships.

A total of 114 invertebrate species were recorded from 25 specimens of Paragorgia arborea and Primnoa resedaeformis collected by ROPOS, Videograb, and otter trawls in the study area (Buhl-Mortensen \& Mortensen 2005). The fauna associated with $P$. resedaeformis was more diverse and abundant than that associated with $P$. arborea and the taxonomic composition of associates was quite different for the two taxa. Rarefaction analysis indicated that many more associated species are still to be found. The numbers of species and individuals were significantly correlated with coral morphology (e.g. number of branches, wet weight, percent exposed skeleton). Crustaceans dominated the fauna, contributing $46 \%$ of the total number of individuals and $26 \%$ of the total number of species. Two coral microhabitats were identified: young and live parts of colonies, and old parts with deposits and exposed skeleton. Most of the associated fauna was found in the latter microhabitat. Sessile hydroids, anemones and molluscs were more abundant on $P$. resedaeformis and were attached to exposed skeleton. Parasitic copepods were more common on P. arborea. The basket star Gorgonocephalus lamarckii was found on the outer branches of $P$. arborea in high current environments. The shrimp Pandalus propinquus was found within colonies of both species.

In the Northeast Channel, a parasitic colonial zoanthid anemone was the most common sessile epibiont observed on Primnoa resedaeformis (Mortensen et al. 2005). On average, it covered about $60 \%$ of the surface of the 28 infected colonies, but one third of the colonies were entirely covered. Hydroids were also frequently found on $P$. resedaeformis (represented with 12 species), but were less common on Paragorgia. arborea (three species). Henry (2001) reports that thirteen hydroid species were found on four coral specimens collected off Atlantic Canada.

Seventeen species of associated crustaceans were identified in seven colonies of Paragorgia arborea and eight colonies of Primnoa resedaeformis sampled with the suction sampler on ROPOS in the depth range of 330$500 \mathrm{~m}$ in the Northeast Channel (Buhl-Mortensen \& Mortensen 2004b). The $P$. arborea fauna was richer than the $P$. resedaeformis fauna in both 
number of species and abundance. Amphipods dominated the fauna but isopods and cirripeds were also common. The most strongly associated crustaceans were two parasitic copepods belonging to a family which is also found on tropical gorgonians and are most likely obligate associates. Shrimp also occurred frequently and most likely seek protection among coral branches from predation. The numerical dominance of amphipods and parasitic copepods is similar to observations made on tropical shallowwater gorgonians but the species richness is higher.

Many of the associated taxa are also found on tropical gorgonians but the deep-water gorgonians lack the diverse decapod and gastropod fauna of their tropical counterparts. The richness of species associated with deep-water gorgonians appears to be higher than reported for tropical shallow-water gorgonians. In contrast to tropical shallow-water gorgonians, deep-water gorgonians have very few obligate symbionts. Nevertheless, several of the species are rare in other habitats and some have been recorded on the same and other gorgonian species in earlier studies.

Anew genus and species of a gall-forming parasitic copepod (Gorgonophilus canadensis) was discovered on specimens of Paragorgia arborea collected from approximately $500 \mathrm{~m}$ in the Northeast Channel by ROPOS and in the Davis Strait by a groundfish trawl survey (Buhl-Mortensen \& Mortensen 2004c). Infection of this endoparasite seems to have little effect on the host. A new species of pedunculate barnacle (Heteralepas cantelli) was discovered on a specimen of Primnoa resedaeformis collected by otter trawl at a depth of about $500 \mathrm{~m}$ on the Scotian Slope (Buhl-Mortensen \& Newman 2004). This is the most northern record of this genus. The gorgonian Trachythela rudis was observed for the first time off Nova Scotia. It occurred as an epizoic on a P. resedaeformis skeleton. Previously, it is known from the fishing banks off Newfoundland (Verrill 1922, Deichmann 1936).

Various taxa of fish were commonly seen associated with corals in the video imagery. The most common was the redfish (Sebastes spp.) which is widely distributed in deep water through out Atlantic Canada, including sites without abundant corals. In the Northeast Channel, redfish were almost four times as common in video sequences with corals than in sequences with boulders but not corals (Mortensen et al. 2005). Twelve taxa of fish were observed along the video transects in the Gully (Mortensen \& BuhlMortensen 2005a). Like the Northeast Channel, the most common species was redfish (Sebastes spp.) which was found on $68 \%$ of the transects. The second most common species was the long-finned hake (Urophycis chesteri) which was found on $51 \%$ of the transects. Redfish were abundant at the site of the Lophelia reef complex at the Stone Fence but the relationship with corals was not significant (Mortensen et al. 2006a).

\section{DAMAGE BY FISHING GEAR}

Fishing gear coming into contact with the seabed has the potential to damage corals, especially the larger taxa (Freiwald et al. 2004). Corals 
are commonly caught as bycatch during commercial fishing operations and research trawl surveys (Table 1). Damaged corals can also be left behind out of sight on the seabed (Mortensen et al. 2005 and Mortensen et al. 2006a). The extent and significance of this damage is currently a matter of debate. Coral communities can probably tolerate a low magnitude and frequency of damage but their slow growth rate of just a few $\mathrm{cm} / \mathrm{y}$ (Mortensen and Buhl-Mortensen 2005b) means that recovery times will be tens to hundreds of years.

\section{Northeast Channel}

As reported by Mortensen et al. (2005), signs of fishing impact in the Northeast Channel were visible as broken live corals, tilted corals and scattered skeletons. Broken or tilted corals were observed on $29 \%$ of the transects and were not concentrated in any particular area. In total, $4 \%$ of the observed colonies were damaged. A higher percentage of Paragorgia arborea colonies was damaged compared to Primnoa resedaeformis $(7.9 \%$ versus $3.4 \%$ ). This is most likely due to its larger size and less flexible skeleton. It appears that damage may make corals more susceptible to parasites since the parasitic anemone was more common on damaged colonies of $P$. resedaeformis than intact ones. Lost longlines were observed loose on the seabed or entangled in corals on $37 \%$ of the transects. Tracks on the seabed, either from longline anchors or parts of otter trawl gear, were present along three transects, while lost gillnets were observed along two transects. With one exception, longlines were only found on transects where coral were present.

\section{Scotian Slope}

No signs of damage to corals were observed in the video footage along the Scotian Slope transects (Mortensen et al. 2006a) despite the fact that the distribution of trawling effort indicates that this region has been quite heavily fished in recent years (Kulka \& Pitcher 2001). This is probably because the dominant species are small, free-living cup corals which are less prone to damage from fishing gear than other coral taxa.

\section{The Gully}

Few signs of fishing damage were observed in the Gully, just a few trawl tracks and one corroded lost wire from a trawl (Mortensen et al. 2006a). Spatial analysis of observer data by Kulka \& Pitcher (2001) indicates that the general area of the Gully was heavily fished with otter trawls during the 1980 s and early 1990 s but that trawling effort then dropped significantly with very little activity in 1998-2000. Canyons are naturally protected against bottom trawling to some degree because of their rugged topography.

\section{Stone Fence}

The Lophelia pertusa reef complex at the Stone Fence was clearly impacted by fishing gear (Mortensen et al. 2006a). All live colonies were either small or clearly broken in an unnatural way. A large rubble zone was evident and 
unusual amounts of pale grey skeletons were present. Gorgonians also showed signs of disturbance in the form of their small size and unnatural occurrence on the sides of and underneath boulders. Many cobbles and boulders showed signs of being overturned. A fragment of a trawl net was also found. Spatial analysis of observer data indicated that the general area of the L. pertusa reef was regularly trawled between 1980 and 2000.

\section{DISCUSSION}

This three-year DFO research project, funded in part by the oil and gas industry, has produced a wealth of new information on the distribution, abundance, habitat and biology of deep-water corals in Atlantic Canada. Data were obtained from DFO groundfish surveys, the Fisheries Observer Program, interviews with fishers and dedicated DFO research cruises with specialized imaging and sampling equipment. The results are in general agreement with the observations of Breeze et al. (1997) but provide much more detail. Nineteen coral taxa were observed. The results confirmed the importance of the Northeast Channel, Gully and Stone Fence as prime coral habitats off Nova Scotia but also demonstrated their abundance off Newfoundland \& Labrador as well as their occurrence at least as far north as Davis Strait. Coral abundance was greatest in the Northeast Channel while diversity was greatest in the Gully. The discovery of the Lophelia reef complex at the Stone Fence marked the first time this taxon has been seen alive in its natural habitat in Atlantic Canada. The most important environmental factors controlling the distribution of corals appear to be substrate, temperature, salinity and currents (which influence food supply). The average height of Primnoa and Paragorgia colonies was 30 and $57 \mathrm{~cm}$ so, at their estimated growth rates of 1.7 and $1 \mathrm{~cm} /$ year, the largest Primnoa colony observed was about 61 years old while the largest Paragorgia colony was about 180 years old. A rich associated fauna of 114 taxa was identified on Paragorgia and Primnoa. Numerous species of fish were also observed associated with deep-water corals, in particular redfish. Damage from fishing gear was most evident at the Lophelia reef complex at the Stone Fence and on gorgonians in the Northeast Channel.

Globally, our understanding of deep-water coral ecosystems and the processes regulating their distribution and behaviour is rudimentary. Nevertheless, it is clear that they represent important biodiversity hotspots and a biological resource with intrinsic and socio-economic value. Because of their longevity, slow growth rates and fragility, they are especially vulnerable to physical damage, in particular bottom fishing activity. Therefore, there is an urgent need to apply some protection from human disturbance.

In 2002, DFO and the fishing industry formed a working group to consider coral protection for the Northeast Channel. After reviewing the results of the video surveys, DFO proposed boundaries for a coral conservation area centered on Romeys Peak because of its high abundance of gorgonians. A fisheries assessment was conducted using available data and discus- 
sions with the working group and at a public meeting led to a greater understanding of the overlap between fishing activities and coral abundance. Adjustments were made to the design of the conservation area taking into consideration the concerns of fishing organizations. A coral conservation area, $424 \mathrm{~km}^{2}$ in size, was formally established by DFO in June 2002 (Mortensen et al. 2005) and slightly modified in 2003. With the exception of $10 \%$ of the area which is open to longline gear, the entire area is closed to all bottom fishing gear.

The results of this project have confirmed earlier observations (Breeze et al. 1997, Maclsaac et al. 2001) that the Gully is indeed a special habitat for deep-water corals. While the average abundance of corals is less than in the Northeast Channel, on the basis of the available data, the species diversity appears to be much greater (compare Table 3 and Table 5). The importance of corals in the Gully played a role in the design of the large Marine Protected Area $\left(2364 \mathrm{~km}^{2}\right)$ that was formally announced by DFO in May 2004.

The discovery of the Lophelia reef complex at the Stone Fence, heavily damaged by fishing activity, led to immediate discussions and meetings regarding establishing a coral conservation area. The need for such a closure to prevent further damage and allow recovery was recognized by all parties, including the fishing industry. After considerable consultation, a $15 \mathrm{~km}^{2}$ coral conservation area centered over the reef complex was established by DFO in June 2004 (Mortensen et al. 2006a).

There still is much that needs to be learned about deep-water corals in Atlantic Canada and research is being continued by DFO and universities. Research priorities have been identified in the Maritimes Region coral conservation plan (DFO 2006). These include continuing to identify important deep-water coral areas, especially at depths below $500 \mathrm{~m}$ which have been poorly sampled to date. Opportunistic sampling of corals continues through the DFO trawl surveys and Fisheries Observer Program in all regions which provide valuable data and samples at practically no cost. Sea-going staff are provided with coral information sheets to improve identification. A coral distribution data base is maintained and updated regularly as new data are obtained. As part of the Discovery Corridor program (Kenchington \& Lawton 2006), coordinated by the Centre of Marine Biodiversity, DFO, Dalhousie University and Memorial University are studying deep-water corals and their habitats in the Jordan Basin, Georges Basin and Northeast Channel using both Campod and ROPOS. The 2006 ROPOS cruise provided the first opportunity to observe corals deeper than $500 \mathrm{~m}$. DFO in the Newfoundland \& Labrador Region has established a long-term research program in collaboration with Memorial University which is placing emphasis on distributional and abundance studies off Newfoundland \& Labrador. It is expected that there will continue to be annual coral research cruises on the C.C.G.S. Hudson to areas of particular interest using both Campod and Videograb (which now have a new $800 \mathrm{~m}$ cable) and ROPOS. These programs will undoubtedly expand our knowledge of deep-water corals still 
further, particularly in regions not yet sampled adequately and at depths greater than $500 \mathrm{~m}$. As well as increasing scientific understanding, these new data will further assist oceans managers in protecting deep-water corals from human disturbance.

Acknowledgements. The major funding for this three-year project was provided by the Environmental Studies Research Funds (ESRF) and the Department of Fisheries and Oceans (DFO). The 2001 ROPOS expedition, led by A. Metaxas of Dalhousie University, was funded in part by the National Scientific and Engineering Research Council (NSERC). P. Mortensen was employed under the NSERC Visiting Fellows in Canadian Government Laboratories program, L. Buhl-Mortensen was employed through a Joint Project Agreement with the Marine Invertebrate Diversity Initiative (MIDI) and S. Gass was employed as a DFO part-time casual employee while working on her master's degree at Dalhousie University. We thank P. Mortensen, L. Buhl-Mortensen, S. Gass, and K. Gilkinson for reviewing this manuscript.

\section{REFERENCES}

Breeze H, Davis DS, Butler M, Kostylev V (1997) Distribution and status of deep sea corals off Nova Scotia. Marine Issues Committee Special Publication No 1, Ecology Action Centre, Halifax, NS

Buhl-Mortensen L, Mortensen PB (2004a) Symbiosis in deep-water corals. Symbiosis 37:3-61

Buhl-Mortensen L, Mortensen PB (2004b) Crustaceans associated with the deepwater gorgonian corals Paragorgia arborea (L., 1758) and Primnoa resedaeformis (Gunn. 1763). J Nat Hist 38:1233-1247

Buhl-Mortensen L, Mortensen PB (2004c) Gorgonophilus canadensisn. gen., n. sp. (Copepoda: Lamippidae), a gall forming endoparasite in the octocoral Paragorgia arborea (L., 1758) from the Northwest Atlantic. Symbiosis 37:155-168

Buhl-Mortensen L, Mortensen PB (2005) Distribution and diversity of species associated with deep-sea gorgonian corals off Atlantic Canada. In: Freiwald A, Roberts JM (eds) Cold-water corals and ecosystems. Springer-Verlag, Berlin, $p$ 849-879

Buhl-Mortensen L, Newman WA (2004) A new pedunculate barnacle (Cirripedia: Heteralepadidae) from the Northwest Atlantic Ocean. Proc Biol Soc Washington 117:385-397

Deichmann E (1936) Alcyonaria of the Western Part of the Atlantic Ocean. Memoirs of the Museum of Comparative Zoology, Harvard University, Cambridge, MA

DFO (Department of Fisheries and Oceans) (2006) Coral conservation plan; Maritimes Region (2006-2010). Oceans and Coastal Management Report 2006-01

Freiwald A., Fosså JH, Grehan A, Koslow T, Roberts JM (2004) Cold-water coral reefs. UNEP-WCMC Biodiversity Ser No 22, Cambridge, UK

Gass SE (2002) An assessment of the distribution and status of deep-sea corals in Atlantic Canada by using both scientific and local forms of knowledge. MSc thesis, Dalhousie University, Halifax, NS

Gass SE, Willison JMH (2005) An assessment of the distribution of deep sea corals in Atlantic Canada by using both scientific and local forms of knowledge. In: Freiwald A, Roberts JM (eds) Cold-water corals and ecosystems. SpringerVerlag, Berlin, p 223-245 
Henry L-A (2001) Hydroids associated with deep-sea corals in the boreal north-west Atlantic. J Mar Biol Assoc UK 81:163-164

Kenchington E, Lawton P (2006) The Discovery Corridor - Exploring our continental shelf and deep-water ecosystems. In: Ryan J (ed) Bedford Institute of Oceanography Annual Review 2005. DFO \& NRCan, Dartmouth, NS, p 43-46

Kostylev VE (2000). Data base on underwater imagery from the Sable Island Gully. Contractors report prepared for DFO, Dartmouth, NS

Kulka DW, Pitcher DA (2001) Spatial and temporal patterns in trawling activity in the Canadian Atlantic and Pacific. Int coun Explor Sea CM 2001/R:02

Maclsaac K, Bourbonnais C, Kenchington E, Gordon DC Jr, Gass S (2001) Observations on the occurrence and habitat preference of corals in Atlantic Canada. In: Willison JHM, Hall J, Gass SE, Kenchington ELR, Butler M, Doherty P (eds) Proceedings of the First International Symposium on Deep-Sea Corals. Ecology Action Centre and Nova Scotia Museum, Halifax, NS, p 58-75

Mortensen PB, Buhl-Mortensen L (2004) Distribution of deep-water gorgonian corals in relation to benthic habitat features in the Northeast Channel (Atlantic Canada). Mar Biol 144:1223-1238

Mortensen PB, Buhl-Mortensen L (2005a) Deepwater corals and their habitats in The Gully, a submarine canyon off Atlantic Canada. In: Freiwald A, Roberts JM (eds) Cold-water corals and ecosystems. Springer-Verlag, Berlin, p 247-277

Mortensen PB, Buhl-Mortensen L (2005b) Morphology and growth of the deepwater gorgonians Primnoa resedaeformis and Paragorgia aborea. Mar Biol 147:775-788

Mortensen PB, Buhl-Mortensen L, Gordon DC Jr, Fader GBA, McKeown DL, Fenton DG (2005) Effects of fisheries on deepwater gorgonian corals in the Northeast Channel, Nova Scotia. Am Fish Soc Symp 41:369-382

Mortensen PB, Buhl-Mortensen L, Gass SE, Gordon DC Jr, Kenchington ELR, Bourbonnais C, Maclsaac KG (2006a) Deep-water corals in Atlantic Canada: A summary of ESRF-funded research (2001-2003). Can Gov't Environmental Studies Research Fund Report 143

Mortensen PB, Buhl-Mortensen L, Gordon DC Jr (2006b) Distribution of deepwater corals in Atlantic Canada. In: Suzuki Y, Nakamori T, Hidaka M, Kayanne $\mathrm{H}$, Casareto BE, Nadaoka K, Yamano H, Tsuchiya M (eds) Proceedings of the $10^{\text {th }}$ International Coral Reef Symposium. Japanese Coral Reef Society, Tokyo, p 1832-1848

Ramp SR, Schultz RJ, Wright WR (1985) The deep flow through the Northeast Channel, Gulf of Maine. J Phys Oceanogr 15:1790-1808

Tunnicliffe V, Syvitski JPM (1983) Corals move boulders: an unusual mechanism of sediment transport. Limnol Oceanogr 28:564-568

Verrill AE (1922) The Alcyonaria of the Canadian Arctic expedition, 1913-1918, with a revision of some other Canadian genera and species. Report of the Canadian Arctic Expedition 1913-18, Volume 8: Molluscs, echinoderms, coelenterates, etc, Part G: Alcyonaria and actinaria. FA Acland, Ottawa, ON 